\title{
AMBROŻY O STAROŚCI W SWOICH LISTACH
}

\author{
„Podoba mi się już to, co łatwiej udaje się starcom: \\ pisać listy w zwyczajnym i poufałym języku" \\ Ambrosius, Ep. 32, 7
}

Gdy w 374 r. Ambroży rozpoczynał swoją kościelną karierę miał prawdopodobnie zaledwie około trzydziestu pięciu lat, gdy zaś umierał w 397 r., około sześćdziesięciu ${ }^{1}$. Trudno więc powiedzieć, że osiagnnął wiek starości, choć sam za takiego się uważał, będąc w wieku około pięćdziesięciu lat ${ }^{2}$. W ciągu 23 lat posługi biskupiej w Mediolanie prowadził ożywioną korespondencję zarówno z osobami bardzo młodymi, jak i z tymi w podeszłym już wieku. Spośród 91 zachowanych listów, cztery skierował do dopiero wchodzącego w życie, młodego cesarza Walentyniana, wiele innych napisał do może niewiele starszych od siebie ludzi, takich jak ukochana siostra Marcelina, kapłan Symplicjan, ale także z pewnością do starszego już wiekiem Euzebiusza, który korespondując z nim miał wnuka Faustyna ${ }^{3}$. Jak zauważa J. Naumowicz we Wstępie do polskiego przekładu listów Ambrożego, jego korespondencja ,jest żywym odbiciem działalności duszpasterskiej i społecznej biskupa Mediolanu. [...] Nie brak w nich mądrości i wiary, rzymskiego rozsądku i zdecydowania, ale także serdeczności i ciepła przyjaźni”" . W listach tych, jako odbiciu codziennego życia, biskup Ambroży nie tylko odnosił się do osób starszych, ale również poruszał problem starości i ludzi starszych. Już chociażby cytat zawarty w tytule tego artykułu, pochodzący z listu Do Syagriusza, napisanego po roku

\footnotetext{
${ }^{1}$ Por. M.G. Mara, Ambrogio di Milano, DPAC I 147-150; J. Quasten, Patrology, IV, Westminster 1995, 144-150; B. Ramsey, Ambrose, London - New York 1997, 15-21.

${ }^{2}$ Por. Epistula 37, 2.

${ }^{3}$ Por. Epistula 26 i 38. O listach św. Ambrożego zob. G. Mamone, La forma delle lettere di S. Ambrogio, „Didaskaleion” 2 (1924) 144-164; G. Mamone, Le epistole di S. Ambrogio, „Didaskaleion” 2 (1924) 3-143; J. Czuj, Święty Ambroży w świetle swoich listów, Warszawa 1939; C.G. Sullivan, The character of St. Ambrose as revealed in his Letters, „Orpheus” 13 (1966) 27-49; M. Zelzer, Plinius Christianus: Ambrosius als Epistolograph, StPatr 23 (1989) 203-208; M. Zelzer, Zur Komposition der Briefsammlung des hl. Ambrosius, StPatr 18/4 (1990) 212-217.

${ }^{4}$ J. Naumowicz, Wstęp, w: Św. Ambroży z Mediolanu, Listy, tłum. P. Nowak, t. 1, BOK 9 , Kraków 1997, 13-14.
} 
380, a więc w okresie dojrzałego życia biskupa Mediolanu, wskazuje zarówno na działalność pisarską, która wypełniała codzienność Ambrożego i dążenie do perfekcji w niej, jak i na pewne cechy osób starszych, czy może raczej okresu życia, jakim jest starość, które są pożądane przez będącego w kwiecie wieku biskupa. Warto więc przyjrzeć się, w jaki sposób, w tych przecież najbardziej prywatnych, i jak się wydaje, najmniej dopracowanych pismach Ambrożego, jakimi są listy, odnosi się on do zagadnienia starości i do osób starszych. Problem ten nie był do tej pory dogłębniej przestudiowany ${ }^{5}$, a F. Trisoglio, autor ostatniego podstawowego opracowania o starości w twórczości Ambrożego, wskazuje, że tematyka ta u niego ma znaczenie marginalne i fragmentaryczne ${ }^{6}$.

W liście 31. (do Oroncjana), w którym biskup Mediolanu w sposób alegoryczny interpretuje opis stworzenia świata według Księgi Rodzaju, a przede wszystkim liczby tam występujące, nadaje siódemce - hebdomadzie - interpretację, która w naszych rozważaniach ma znaczenie zasadnicze:

„Niech więc się święci hebdomadę, dlatego że życie ludzi przebiega przez siedem okresów wieku aż do starości, jak w swoich pismach wyjaśnił Hipokrates, mistrz medycyny. Pierwszym wiekiem jest niemowlęctwo, drugim dzieciństwo, trzecim wiek młodzieńczy, czwartym młodość, piątym wiek męski, szóstym wiek dojrzały, siódmym starość. Jest więc człowiek niemowlęciem, dzieckiem, chłopakiem, młodzieńcem, mężczyzną, weteranem, i starcem. Solon zaś wyróżnił dziesięć etapów wieku po siedem lat każdy, tak iż pierwszy wiek niemowlęcy trwa aż do wyrośnięcia zębów, za pomocą których dziecko gryzie pokarm i wypowiada słowa, aby mogło ujawnić swoją zdolność do mówienia; dzieciństwo dochodzi aż do lat dojrzewania i pełnego rozwoju genitaliów; wiek młodzieńczy aż do pierwszego zarostu na brodzie; młodość aż do osiagnięcia pełnej siły; piąty wiek męski jest odpowiedni do stosunków małżeńskich przez całą hebdomadę; także szósta hebdomada jest zaliczana do wieku męskiego, sprzyjającego wzrastaniu w roztropności oraz przedsiębiorczego w działaniu; również siódma i ósma hebdomada wieku ujawniają osobowość dojrzałą i w pełni władz umysłowych, a także zdolność mówienia, wyposażoną w dar unikania nieprzyjemnych słów; dziewiąta hebdomada, subtelniejsza w języku i mądrości, ma jeszcze pewne resztki sił; natomiast dziesiąta hebdomada do-

${ }^{5}$ Istnieje bardzo skapa literatura na temat rozumienia starości przez Ambrożego, oprócz poniższego artykułu F. Trisoglio można wskazać np. E. Lamirande, Les ages de l'homme d'après Saint Ambroise de Milan (397), „Cahiers des Études Anciennes” 14 (1982) 227-233; E. Lamirande, Âges de l'homme et âges spirituels selon saint Ambroise. Le Commentaire du psaume 36, „Science et Esprit" 35 (1983) 211-222; G. Doenni, Der alte Mensch in der Antike: ein Vergleich zwischen christlicher und paganer Welt anhand der Aussagen von Hieronymus, Augustinus, Ambrosius und Cicero, Bamberg 1996.

${ }^{6}$ Por. F. Trisoglio, Sant'Ambrogio e la vecchiaia, w: Senectus. La vecchiaia nell'antichità, ed. U. Mattioli, t. 3: Ebraismo e cristanesimo, Bologna 2007, 449-477, spec 449. 
pełnia miary; ten, kto zdoła ją osiagnąć, w dojrzałym wieku zapuka wieczorem do przedsionków śmierci. Zatem Hipokrates i Solon znali albo siedem okresów albo siedmioletnie okresy życia ludzkiego"7.

W teologiczny wywód wprowadza Ambroży rozważania dotyczące podziału życia ludzkiego, w oparciu o znaczenie liczby siedem. Powołując się na Hipokratesa i Solona, rozróżnia siedem jego okresów lub siedmioletnie jego podziały, jednak dla naszych rozważań ważne jest, że przywołuje jednocześnie cechy poszczególnych okresów, podkreślając dojrzałość, subtelność i mądrość okresu starości. Podążanie za pogańskimi filozofami i medykami nie wprowadza jeszcze chrześcijańskiej wizji starości, ale daje podstawę do budowania takiej wizji w swych wypowiedziach.

Rozszerzenie tej pogańskiej wizji znajdujemy w liście 52. skierowanym do Anyzjusza, po objęciu przez niego stolicy biskupiej w Tesalonice po śmierci biskupa Acholiusza, gdzie Ambroży, można powiedzieć, przedstawia definicję starości, która zbliża się już do wizji chrześcijańskiej. Biskup Mediolanu stwierdza:

„[...] Cóż bowiem stanowi prawdziwie starczy wiek, jeśli nie życie nieskalane, które rozciaga się nie na dni czy miesiące, lecz na wieki, którego trwanie jest bez końca, a długowieczność bez słabości? Im bowiem dłużej trwa, tym jest mocniejsze, a im dłużej ktoś żyje tym życiem, z tym większą siłą wzrasta, aż stanie się człowiekiem doskonałym"».

Według zatem biskupa Mediolanu, starość mierzy się zasługami, a zasługuje ona na szacunek ze względu na czystość myśli i czynów. Podkreśla jedno-

${ }^{7}$ Epistula 31 (ad Orontianum), 12-14, CSEL 82/1, 222-223: „Celebretur itaque ebdomas eo quod per septem aetatum cursus vita hominum usque ad senectutem transcurritur, sicut Hippocrates, medicinae magister, scriptis explicuit suis. Prima aetas infantia est, secunda pueritia, tertia adulescentia, quarta iuventas, quinta virilis aetas, sexta aevi maturitas, septima senectus. Est ergo infans, puer, adulescens, iuvenis, vir, veteranus, senex. Solon autem decem fecit aetatum ordines per annos septenos, ita ut prima aetas infantiae usque ad emissionem sit dentium, quibus conficiat cibum sermonemque distinguat, ut possit effabilis videri, pueritia quoque usque ad annos pubertatis procedit et genitalia testamenta, adulescentia usque ad barbae lanuginem, iuventas usque ad perfectae virtutis processum, quinta aetas virilis est, apta copulis coniugalibus per totam ebdomadem, sexta quoque ebdomas virili deputatur aetati et ad prudentiae processum habili et ad agendum strenuae, septima quoque ebdomas et octava aevi maturum et sensu vigentem et sermonem item non insuavis adloquii gratia praeditum produnt, nona ebdomas reliquias adhuc habet aliquas virium mollior lingua ac sapientia, decima vero ebdomas mensuram implet, ad quam is qui pervenire potuerit, non inmaturo temporum cursu pulsabit mortis sera vestibula. Ergo Hippocrates et Solon vel septem aetates vel ebdomadas aetatum norunt. In illis se ebdomas praeferat, octava autem unam et perpetuam aetatem invehit, qua excrescimus in virum perfectum in agnitione dei, fidei plenitudine, in qua legitimae aetatis mensura impletur", thum. P. Nowak, BOK 9, 234-235.

${ }^{8}$ Epistula 52 (ad Anysium), 5, CSEL 82/2, 70: „Quae est enim verae aetas senectutis nisi vita immaculata, quae non diebus aut mensibus sed saeculis propagatur, cuius sine fine est diuturnitas, sine debilitate longaevitas? Quo enim diuturnior, eo fortior; et quod diutius eam vitam vixerit, in virum perfectum excrescit”, thum. P. Nowak, BOK 20, 51. 
cześnie Ambroży proces dorastania do okresu starości i dojrzewania do doskonałości, która jest cechą starości, jak to można zauważyć chociażby w powyższych cytatach. W sposób wyraźny i chrześcijański wskazuje zaś na takie pojmowanie okresu starości w dalszej części cytowanego już listu 31:

„[...] oktawa wprowadza jeden i nieprzerwany okres, w którym dorastamy do człowieka doskonałego w poznaniu Boga, w pełni wiary, w której dopełnia się miara odpowiedniego wieku".

Okres starości jest więc według biskupa Mediolanu okresem doskonałości, jest okresem dorastania do człowieka doskonałego, a może raczej dopełniania i wieńczenia tego dorastania. Starość jest czasem, w którym człowiek staje się naprawdę doskonały w znaczeniu ludzkim, a przede wszystkim w znaczeniu moralnym i religijnym, co możliwe jest tak naprawdę dopiero u kresu życia ${ }^{10}$. Takie pojmowanie starości opisuje Ambroży również w liście 16:

„Kto zaś jest mężem doskonałym, jeśli nie ten, kto uwolniony od dziecinności dziecięcego sposobu myślenia, od niepewnego i swawolnego zachowania wieku chłopięcego, i od nieumiarkowanego żaru młodości, osiagnął stałość „męża doskonałego”, i doszedł do takiej dojrzałości obyczajów, że niełatwo odwraca się od prawdy pod wpływem przemówienia jakiegoś głosiciela błędów, ani nie jest rzucany o skały, jakby przez bardzo gwałtowną burzę nierozumnej nauki, uciekając się do lekarstwa przeciwko błędowi? Idzie on za prawdą nie tylko w słowach, lecz także w swoich uczynkach i przyjmuje w sobie zbudowanie miłości, aby w jedności wiary i poznania iść naprzeciw i - by jako członka Ciała - nie brakowało go swej Głowie, to jest Chrystusowi, który jest Głową wszystkich"11.

Starzec zatem odznacza się dojrzałym sposobem myślenia, statecznością, a więc wszystkim tym, co ma wymiar ludzki, ale według Ambrożego starość ma również wymiar eklezjalny - można powiedzieć, że człowiek stary jest dojrzały

${ }^{9}$ Epistula 31, 14, CSEL 82/1, 223: ,[...] octava autem unam et perpetuam aetatem invehit, qua excrescimus in virum perfectum in agnitione dei, fidei plenitudine, in qua legitimae aetatis mensura impletur", BOK 9, 235.

${ }^{10}$ Por. Lamirande, Âges de l’homme, s. 211. O doskonałości chrześcijańskiej i nabywaniu cnót u Ambrożego zob. J. Pałucki, Nabywanie cnót $w$ ambrozjańskim programie doskonalenia chrześcijańskiego, w: Droga doskonalenia chrześcijańskiego w epoce patrystycznej, red. F. Drączkowski - J. Pałucki - M. Szram, Lublin 1997, 77-82; tenże, Święty Ambroży jako duszpasterz w świetle ekshortacji pastoralnych, Lublin 1996, 119-176.

${ }^{11}$ Epistula 16 (ad Irenaeum), 12, CSEL 82/1, 120-121: „Quis autem vir perfectus est nisi ille, qui absolutus infantia puerilis ingenii adque adulescentiae incerto ac lubrico et inmoderato iuventutis calore in 'viri perfecti' firmitatem successerit adque ad illam morum maturitatem adoleverit, ut non facile devii disputatoris adloquio flectatur et quasi quadam doctrinae inrationabilis turbidiore in scopulos iactetur procella, ad erroris remedia se conferens, et qui veritatem non solum in sermone, sed etiam in operibus sequatur suis et aedificationem caritatis in se suscipiat, ut in unitate fidei et agnitionis occurrat et quasi membrum non desit capiti suo, id est Christo, qui est caput omnium [...]”, BOK 9, 135. 
i stateczny eklezjalnie. Starzec bowiem w swej stałości nie poddaje się wpływowi herezji i błędnych nauk, nie podąża łatwo za zwodzicielami, ale trzyma się prawdziwej nauki Kościoła, który jest Ciałem Chrystusa. Starzec poznał Boga, przyoblekł się w Chrystusa, stał się przybranym synem i osiagnął pełnię wiary ${ }^{12}$.

Inny wymiar starości w korespondencji Mediolańczyka można dostrzec w cytacie, stanowiącym część podtytułu niniejszego opracowania. Ambroży wyraża w nim podziw dla sposobu wyrażania się ludzi starszych i sposobu pisania listów, który jako człowiek wykształcony na klasycznych wzorach i nawiązujący do mores maiorum uważał za godny naśladowania. Wskazuje, że listy ludzi starszych odznaczają się zwyczajnym i poufałym językiem; są oni również biegli w Piśmie Świętym, skoro bez trudu wplatają jego fragmenty w pisane listy. W cytowanym liście 31 . Ambroży zwraca również uwagę na tę cechę ludzi starszych stwierdzając, że ludzie w siódmej i ósmej hebdomadzie posiadają zdolność mówienia „wyposażoną w dar unikania nieprzyjemnych słów”, a ich hebdomada dziewiąta jest jeszcze subtelniejsza w języku i mądrości ${ }^{13}$. Wydaje się, że Ambroży, piszący te słowa w wieku około lat pięćdziesięciu, jako wykształcony na wzorach senium, tęskni do tej zdolności doskonałych ludzi starszych i stawia ją sobie za wzór do naśladowania ${ }^{14}$. Świecki jednak charakter tej cechy - umiejętność posługiwania się słowem - uzupełnia on jeszcze o wymiar chrześcijański - posługiwanie się Pismem Świętym - i w ten sposób dopełnia jakby miary doskonałości wieku starczego do pełni chrześcijanina.

Pomimo że Ambroży wskazuje jednoznacznie na okresy życia ludzkiego oraz czas ich trwania, przyznając starości okres po pięćdziesięciu latach, to jednak wskazuje, że nie tylko latami i siwymi włosami się ją mierzy. Można to odczytać już w powyższych wypowiedziach, gdy traktuje jąjako okres dojrzałości i pewnej pełni. W sposób jednak wyraźny pisze o tym w liście 52:

„[...] czcigodna jest ta starość, która bieleje nie siwizną włosów, lecz zasługami; ta bowiem siwizna zasługuje na poważanie, która jest siwizną duszy, jaśniejącą w czystych myślach i uczynkach"15.

Dla Ambrożego - który posługuje się egzegezą alegoryczną - mówienie o starości i charakteryzującej ją siwiźnie jest okazją do ukazania moralnego wymiaru starości oraz pokazania, że cechy moralne, które powinny być charakterystyczne dla starców, winny być również obecne w ludziach młodych. Dlatego też w ostatnim ze znanych listów, w liście 14*. z 396/397 r. skierowanym do Kościoła w Vercelli, zachęcając tamtejszą wspólnotę do wstrzemięźliwości, postów i umiarkowania, pisze:

${ }^{12}$ Por. Epistulae 20, 9 i 31, 14.

${ }^{13}$ Por. Epistula 31, 13. Tekst oryginalny wyżej, n. 7.

${ }^{14}$ Por. Epistula 28, 16.

${ }^{15}$ Epistula 52, 5, CSEL 82/2, 69-70: „Vere senectus illa venerabilis, quae non canis, sed meritis albescit. Ea est enim reverenda canities, quae est canities animae in canis cogitationibus et operibus effulgens", BOK 20, 51. 
„Cóż zaś jest piękniejszego od wstrzemięźliwości, która także lata młodości czyni dojrzałymi, aby odznaczała się ona obyczajami starości?’"16.

Zatem również młodzieniec może odznaczać się cechami starca, może osiągnąć dojrzałość charakterystyczną dla wieku starczego. Nieco dalej w tym samym liście, jakby nawiązując do tej myśli, biskup Mediolanu stwierdza:

„I młodzi mogą okazać się dojrzałymi przez swoje obyczaje i starzy mogą być młodymi przez swoje czyny. Albowiem to dyscyplina, bardziej niż wiek, przynosi poprawę obyczajów ${ }^{17}$.

Praca nad sobą więc oraz doskonalenie się w cnotach pozwalają osiągnąc stan dojrzałości i doskonałości chrześcijańskiej, charakterystycznej starcom (senectutis maturitas). W tym jednak konieczna jest pomoc Boża, jak o tym stwierdza Ambroży w liście do młodego cesarza Walentyniana ${ }^{18}$.

Starość jednak według Ambrożego, oprócz dojrzałości, doskonałości, osiągnięcia cnót i innych blasków, ma również swoje cienie. Według biskupa charakteryzuje się ,starczą słabością" ${ }^{19}$, zachowuje „pewne resztki sił" ${ }^{20}$, i ostatecznie, kto ją osiagnie „wieczorem zapuka do przedsionków śmierci” ${ }^{21}$. Obrazowo te starcze niedogodności przedstawia Ambroży w liście 57., w którym dokonuje egzegezy 19 i 21 rozdziału Księgi Sędziów, poświęcając szczególną uwagę czystości. W tym celu przywołuje historię starca, który nie chcąc pozwolić na pohańbienie gości, ofiarowuje żądnym „rozrywek” Gibeonitom swoją córkę dziewicę. W tym opisie gibeoniccy młodzieńcy przedstawieni są jako: „oddani wszelkiej rozpuście, niemający nic z rozwagi czy umiarkowania, których uroda kobiety uwiodła i doprowadziła do zupełnego szaleństwa"22. Jak widać, taki opis wieku młodzieńczego jest całkowitym przeciwieństwem wyżej omówionego okresu starości, jednak w naszych obecnych rozważaniach ważniejsze są cechy, jakie przypisuje starcowi Ambroży. Pisze on, że młodzieńcy:

„zniewoleni jej pięknością i spodziewając się [łatwo] osiągnąć cel z powodu starości gospodarza i słabej pomocy, [na jaką mógł liczyć], domagają się kobiety i stukają do bramy. [...] Tak więc, gdy na nic się nie zdały pobożne

${ }^{16}$ Epistula 14* (Maur. 63 : ad episcopum Vercellensem), 26, CSEL 82/3, 249: „Quid autem pulchrius abstinentia, quae facit etiam iuventutis annos senescere ut fiat morum senectus?", thum. P. Nowak, (tłumaczenie zawarte w przygotowywanym do druku III tomie Listów św. Ambrożego, użyczone dzięki uprzejmości tłumacza).

${ }^{17}$ Tamże 98, CSEL 82/3, 288: „[...] cum possit et iuventus senescere moribus et senectus virere operibus. Neque enim emendationem morum magis aetas affert quam disciplina”, thum. P. Nowak.

${ }^{18}$ Por. Epistula 75 (ad Valentinianum), 5.

${ }^{19}$ Epistula 16, 5, CSEL 82/1, 116: „senilis infirmitatis”, BOK 9, 132.

${ }^{20}$ Epistula 31, 13, CSEL 82/1, 223: „reliquias adhuc habet aliquas virium”, BOK 9, 235.

${ }^{21}$ Epistula 31, 13, CSEL 82/1, 223: „non inmaturo temporum cursu pulsabit mortis sera vestibula", BOK 9, 235.

${ }^{22}$ Epistula 57, 7, CSEL 82/2, 103: ,[...] iuvenes ad omnem proiecti libidinem, nihil pensum ac moderatum habentes, quos forma mulieris illexerat et in omnem amentiam praecipitabat", BOK 20, 83. 
prośby i gospodarz na próżno wyciągał starcze ręce, bez nadziei na jakąś pomoc, kobieta została porwana i przez całą noc poddana znieważaniu"23.

Gospodarz starzec ukazany jest z jednej strony jako sprawiedliwy, wstawiający się za krzywdzonymi, pobożny, z drugiej zaś podkreślone są słabości okresu starczego: owe słabe, starcze ręce, jakaś bezradność i fizyczna niemoc.

Starość może być, według Ambrożego, niebezpieczna także z innego powodu - mianowicie dlatego, że - jak pisze w liście 50., interpretując wydarzenie z kobietą pochwyconą na cudzołóstwie i odstąpienie starszych jako pierwszych od jej ukamienowania - „,i, którzy dłużej żyli, mieli więcej grzechów”. Zaraz jednak biskup dodaje - doceniając okres starości - że „oni, jako mądrzejsi, pierwsi pojęli moc tego wyroku, i zaczęli bardziej opłakiwać swoje grzechy ci, którzy przyszli jako oskarżyciele cudzego występku" ${ }^{24}$. Starość ma więc swoje niedogodności i wady, jednak również, a może przede wszystkim, pozytywne wymiary objawiające się w większej mądrości. Wydaje się, że za tymi ułomnościami starczymi stoi według Ambrożego tak naprawdę sam diabeł, którego nazywa za Księgą Koheleta „królem starym i głupim”, który „gdy chce królować jako pan swojej własnej woli i nie być skrępowany więzami Pana Jezusa, zastarzały w grzechach, popada w hańbę głupoty"25, w przeciwieństwie do Chrystusa, który kilka wersów wcześniej określany jest jako „chłopiec” (puer), a więc synonim młodości ${ }^{26}$. Poddanie się diabłu jest więc poddaniem się starczej słabości, głupocie i grzechowi, zaś oddanie się Chrystusowi jest mocą, wyzwoleniem i młodością pomimo przeżytych lat ${ }^{27}$.

Słabość ciała, zaawansowany wiek i inne niedoskonałości starczego wieku nie stanowią jednak, według Ambrożego, przeszkody w tym, co stanowi tak naprawdę istotę starości ukazaną powyżej. Dlatego też do wspomnianego wyżej biskupa Anyzjusza pisał:

${ }^{23}$ Epistula 57, 8 i 9, CSEL 82/2, 103-104: „Capti enim eius decore et per senectutem hospitis atque infirmitatem subsidii accepta spe potiundi poscunt mulierem et pulsant ianuam. [...] Itaque cum piae nihil proficerent preces et seniles frustra hospes manus tenderet desperato praesidio rapitur mulier et per totam noctem iniuriae impletur", BOK 20, 83-84 (ze zmianami moimi-M.W.).

${ }^{24}$ Epistula 50, 6, CSEL 82/2, 58: „Audientes illi exire coeperunt singuli incipientes a senioribus, vel quod ipsi plura haberent crimina qui diu vixerant, vel quia priores vim intellexerunt sententiae quasi prudentiores. Et coeperunt sua magis peccata deflere qui alieni criminis venerant accusatores", BOK 20, 44.

${ }^{25}$ Epistula 17, 12, CSEL 82/1, 126: „Sub hoc ergo vivamus, ut 'rex ille senior et stultus' potestatem supra nos habeat nullam, qui, dum vult regnare, quasi voluntatis suae dominus nec sub vinculis esse domini Iesu, inveteratus in peccatis stultitiae incidit deformitatem”, BOK 9, 141.

${ }^{26}$ Por. M. Bambeck, „Puer und puella senes” bei Ambrosius v. Mailand. Zur altchristlichen Vorgeschichte eines literarischen Topos, „Romanische Forschungen” 84/3 (1972) 297-313.

${ }^{27}$ Por. G.J.M. Bartelink, „Fragilitas humana” chez Saint Ambroise, w: Ambrosius Episcopus. Atti del Congresso internazionale di studi Ambrosiani nel XVI centenario della elevazione di Sant'Ambrosio alla cattedra episcopale (Milano, 2-7 dicembre 1974), ed. G. Lazzati, II, Milano 1976, 130-142. 
„W tobie szuka się Acholiusza; i jak to było w twoich uczuciach, tak również w twoim posługiwaniu pragnie się widzieć obraz tej cnoty, tej dyscypliny, siłę tego ducha, jakie on miał w swym starczym ciele"28.

O znaczeniu i wielkości starości świadczy więc wzmiankowana już wielokrotnie, osiagnięta doskonałość w cnotach i rozwój duchowo-moralny. Ten, kto u kresu fizycznego życia osiągnął ten stan, nie musi się bać fizycznych oznak starości, bo jak zauważono to już wcześniej, wychodzi on w ten sposób na spotkanie Chrystusa ${ }^{29}$.

Ze starością według Ambrożego wiążą się także pewne „przywileje” i prerogatywy, które niedostępne są innemu wiekowi. I tak w swoich listach biskup Mediolanu wskazuje, że starcy pełnią rolę świadków: to oni świadczą i przekazują informacje o dawnych wydarzeniach i o przeszłości. Taką rolę starszych opisuje Ambroży, gdy opowiada o odnalezieniu relikwii świętych Protazego i Gerwazego: prawdziwość relikwii i ich historię potwierdzają właśnie starcy, którzy „powtarzają że kiedyś słyszeli imiona tych męczenników i czytali ich napis nagrobny" ${ }^{30}$. Starcy są także mędrcami, którzy podsuwają rozwiązania trudnych sytuacji, zapewniające pomyślność i trwanie narodów ${ }^{31}$.

Ambroży stawia przed starcami również szczególne zadania wynikające $\mathrm{z}$ ich prerogatyw i cech. W jednym $\mathrm{z}$ listów interpretując $-\mathrm{w}$ kontekście sporu z arianami o świątynię mediolańską - zdanie o kamieniach, które wołać będą (Łk 19,40), biskup Mediolanu przypomina, że jedną z grup obrazujących owe kamienie, są właśnie starcy, którzy przez swoją dojrzałość i umocnienie w wierze są szczególnie uprawnieni do wyrażania sprzeciwu i wołania o prawdę. Dlatego stwierdza:

„Wołać będą także starcy - czyli te kamienie już umocnione na tym kamieniu, o którym jest napisane: Kamień odrzucony przez budujących stał się kamieniem węgielnym" ${ }^{\prime 2}$.

W kontekście całego listu można więc stwierdzić, że to właśnie starcy mogą odgrywać szczególną rolę w rozwiązaniu sporu o świątynię, a także we wszelkich dyskusjach z heretykami. Co więcej, Ambroży wskazuje w tymże liście,

\footnotetext{
${ }^{28}$ Epistula 52 (ad Anysium), 1, CSEL 82/2, 68: „Quaeritur in te Acholius, et sicut erat in affectu tuo, ita in officiis desideratur illius virtutis, illius disciplinae effigies, illius fortitudo animi in tam senili corpore", BOK 20, 50.

${ }^{29}$ Por. wyżej, n. 11.

${ }^{30}$ Epistula 77, 12, CSEL 82/3, 134: „Nunc senes repetunt audisse se aliquando horum martyrum nomina titulumque legisse", thum. P. Nowak, (thumaczenie zawarte w przygotowywanym do druku III tomie przekładu Listów św. Ambrożego).

${ }^{31}$ Por. Epistula 57, 16, CSEL 82/2, 109-110.

${ }^{32}$ Epistula 75a (Sermo contra Auxentium), 20, CSEL 82/3, 95: „,...] clamabunt et senes, isti lapides ad illum iam solidati lapidem, de quo scriptum est: Lapidem quem reprobaverunt aedificantes hic factus est in caput anguli", tłum. P. Nowak, (thumaczenie zawarte w przygotowywanym do druku III tomie przekładu Listów św. Ambrożego).
} 
że właśnie w takich trudnych sytuacjach, kwestiach spraw wiary i dyscypliny kościelnej, to zdanie i modlitwa starców, na równi z innymi, którzy zdają się być wydawałoby się słabymi ludźmi, mają szczególną moc:

„Oby mi zawsze przypisywali to przewinienie, że złoto rozdaje się ubogim! Jeśli zaś mi zarzucą, że szukam ich obrony, nie zaprzeczam, lecz [przyznam się, że] nawet o nią się staram. Mam obronę, ale w modlitwach ubogich. Ci niewidomi i chromi, ułomni i starcy są mocniejsi od krzepkich wojowników"333.

Mediolańczyk jednak zdaje sobie sprawę, że nie wszyscy ludzie starzy są W stanie sprostać zadaniom stawianym przed nimi i nie wszyscy posiadają cechy, które Ambroży przypisuje prawdziwym „starcom”. W liście do swej siostry Marceliny z 386 r. ubolewa, że istnieją starsi, którzy nie spełniają wyżej opisanego ideału starca:

Jestem słabszy, a niebezpieczeństwo większe. Następują po sobie intrygi kobiet, pojawiają się kolejne nienawiści, zmieniają się zmyślone [informacje], zbierają się starsi, jako pretekst zarzuca się królewską zniewagę. Jaki więc jest powód cięższego kuszenia przeciwko temu robaczkowi, jeżeli nie to, że nie mnie prześladują, lecz Kościół? ${ }^{34}$.

Owi starsi wpisują się niestety w działalność przeciwko prawowitemu biskupowi, w knowania kobiet, nienawiść, plotki i fałszywe oskarżenia, a przede wszystkim w atak na Kościół. W ten sposób stają się oni zaprzeczeniem ideału starca, o którym w innych, powyżej omówionych listach pisze Ambroży.

Jak widać, Ambroży w swej korespondencji stosunkowo wiele miejsca poświęca ideałowi starca, wskazując równocześnie na jego antyideał, ale także ukazuje sposób postępowania wobec starców. W liście 7. mówiąc o źródłach filozofii i interpretując postawę synów Noego podkreśla poniżenie Chama i wywyższenie jego braci za to, że uszanowali starość ojca ${ }^{35}$. Sam zresztą jest przykładem troski i szacunku wobec starszych. W liście 30. skierowanym do cesarza Walentyniana, opisującym poselstwo Ambrożego w Galii do Maksyma, Biskup okazuje postawę troski i szacunku wobec jednego z błądzących biskupów, który został skazany na wygnanie, pisząc w ten oto sposób o całej sytuacji do cesarza:

${ }^{33}$ Tamże 33, CSEL 82/3, 105: „Utinam hoc mihi semper crimen ascribant, quia aurum pauperibus erogatur! Quod si obiciunt quod defensionem ab his requiram non nego sed etiam ambio. Habeo defensionem sed in orationibus pauperum. Caeci illi et claudi, debiles et senes robustis bellatoribus fortiores sunt”, thum. P. Nowak; por. przekład J. Czuja, POK 21, 284.

${ }^{34}$ Epistula 76, 18, CSEL 82/3, 118: „Virtus infirmior sed plus periculi. Succedunt sibi mulierum vices, alternantur odia, commenta variantur, seniores conveniuntur, praetexitur regis iniuria. Quae ratio igitur est adversus hunc vermiculum gravioris temptationis nisi quia non me sed ecclesiam persequuntur?", thum. P. Nowak, (tłumaczenie zawarte w przygotowywanym do druku III tomie przekładu Listów św. Ambrożego).

${ }^{35}$ Por. Epistula 7, 6, CSEL 82/1, 45-46. 
„Później, gdy widział, że stroniłem od tych biskupów, którzy byli z nim zjednoczeni, lub którzy domagali się kary śmierci dla niektórych osób błądzących w sprawach wiary, oburzony tym rozkazał mi, abym niezwłocznie odszedł. Ja zaś chętnie wyruszyłem $w$ drogę powrotną - chociaż wielu nie wierzyło, że uniknę zasadzek - dręczony jednie tym bólem, że dowiedziałem się, iż prowadzono na zesłanie starego biskupa Hygina, któremu nie pozostawało już nic innego, jak tylko wydać ostatnie tchnienie. Kiedy udałem się w tej sprawie do jego hrabiów, aby nie pozwolili wypędzić staruszka bez ciepłego ubrania i bez pierzyny, ja sam zostałem wypędzony ${ }^{36}$.

Ambroży okazuje się więc w tym fragmencie jako współczujący i troskliwy człowiek, który dba o starego biskupa Hygina, chcąc zapewnić mu przyzwoite warunki wygnania, za co sam zostaje wygnany. W ten sposób okazuje też troskę o ludzi starszych, która powinna być domeną wszystkich ludzi, ale wydaje się, że opis ten może mieć również charakter edukacyjny dla odbiorcy listu, który wówczas miał trzynaście lat i który dopiero uczył się władania państwem. Wykazuje tu także Ambroży, że spory i błędy popełniane przez ludzi muszą zostać zapomniane, gdy chodzi o szacunek i troskę o starców.

Innym świadectwem tej troski biskupa Ambrożego jest list 70. skierowany do biskupa Aleksandrii Teofila, w sprawie schizmy antiocheńskiej. W liście tym biskup Mediolanu zwraca uwagę że spór został już załagodzony podczas synodu w Kapui, jednak Flawian powtórnie odwołał się do cesarza, wznawiając tym samym spór, którego rozwiązanie wymagać będzie na nowo zebrań biskupów. I w tym kontekście niepokoił się przede wszystkim o starszych i ubogich biskupów:

„Na próżno więc został włożony wysiłek tylu biskupów? Znowu trzeba zwracać się do sądów świeckich i do rozporządzeń [cesarskich]; znowu starsi biskupi będą utrudzeni, będą przeprawiali się przez morza; znowu - chociaż osłabieni na ciele - opuszczą ojczyznę, [udając się] na obcą ziemię; znowu święte ołtarze będą opuszczone, gdy odjedziemy daleko; znowu tłumy ubogich biskupów dla których przedtem ubóstwo nie było uciążliwe - potrzebując obcej pomocy, będą zmuszone wzdychać nad swą biedą albo przynajmniej zużyć na pokrycie kosztów podróży [środki przeznaczone na] utrzymanie ubogich!"’37.

${ }^{36}$ Epistula 30 (ad Valentinianum), 12, CSEL 82/1, 214-215: „Postea cum videret me abstinere ab episcopis, qui communicabant ei, vel qui aliquos, devios licet a fide, ad necem petebant, commotus eis iussit me sine mora regredi. Ego vero libenter, etsi me plerique insidias evasurum non crederent, ingressus sum iter, hoc solo dolore percitus, quod Hyginum episcopum senem exilium duci conperi, cui nihil iam nisi extremus superesset spiritus. Cum de eo convenirem comites eius, ne sine veste, sine plumacio paterentur extrudi senem, extrusus ipse sum", BOK 9, 227-228.

${ }^{37}$ Epistula 70 (ad Theophilum), 3, CSEL 82/3, 4-5: „Frustra ergo tantorum sacerdotum fusus labor, iterum ad huius saeculi iudicia revertendum, iterum ad rescripta, iterum vexabuntur sacerdotes senes, transfretabunt maria, iterum invalidi corpore patriam peregrino mutabunt solo, iterum sacrosancta altaria deserentur ut in longinqua proficiscamur, iterum pauperum turbae episcoporum, quibus ante onerosa paupertas non erat, externae opis egentes compellentur inopiam gemere aut 
Z pewnościąjest $w$ tym fragmencie wiele retorycznej maniery, ale jednak warte zauważenia jest to, że Ambroży w celu obrony porządku kościelnego używa argumentu ludzi starszych. Zwraca uwagę na niedogodności, które będą musieli znieść starsi biskupi, aby dotrzeć na obrady synodu: podkreśla ich utrudzenie i słabość ciała. W ten sposób okazuje szacunek i troskę o starców, co widoczne było również w wyżej przytoczonym liście.

Omawiając problem starości w listach św. Ambrożego warto zatrzymać się chwilę także na jeszcze jednym wymiarze starości, na który zwraca uwage nasz Biskup używając tego samego słownictwa, którym opisuje starość ludzi, a który wynika z alegorezy, jaką stosuje. Mianowicie w jednym z listów skierowanych do Walentyniana w odpowiedzi na argumenty przedstawione przez prefekta Rzymu Symmacha, usiłującego przekonać cesarza do przywrócenia ołtarza ofiarnego w senacie, Ambroży dotyka znów problemu starości, tym razem jednak nie starości człowieka, ale starości rzeczywistości ziemskich. W liście tym, w retorycznej formie, biskup przedstawia przemowę Rzymu:

„Żałuję swoich błędów, moja sędziwa siwizna zawstydzona okryła się czerwienią z powodu krwi haniebnie przelanej. Lecz nie rumienię się, gdy nawróciłem się w podeszłym wieku, razem $\mathrm{z}$ całym światem. $Z$ pewnością jest prawda, że w żadnym wieku nie jest za późno na naukę. Niech rumieni się ta starość, która nie potrafi się poprawić. Godna pochwały jest nie starość lat, lecz obyczajów. To żaden wstyd przejść do rzeczy lepszych. Tylko to miałem wspólnego z barbarzyńcami, że przedtem nie znałem Boga"38.

Oczywiście, nie chodzi o analizę retorycznego popisu biskupa Mediolanu, ale raczej o wydobycie tego, co zawsze dla niego było najważniejsze - nawrócenia i doskonałości chrześcijańskiego życia. Przemawiający Rzym jest upersonifikowanym starcem, który pomimo swego wieku nawraca się, poznaje Boga i zaznacza, że zawsze jest czas i możliwość poprawy, a przede wszystkim podkreśla cechę starości, o której była już mowa powyżej, jaką jest dojrzałość obyczajów i dojrzałość moralna. W tym samym liście Ambroży raz jeszcze powraca do tematyki wieku i starości, jednak tym razem mówi o starości świata: podobnie jak w przypadku starego Rzymu, tak i w przypadku starego świata, podkreślone zostaje jego nawrócenie w późnym wieku i dojrzałość wiary, którą cechuje się czcigodna starość ${ }^{39}$.

certe victum inopum itineris < sumptui> usurpare!", tłum. P. Nowak, (thumaczenie zawarte w przygotowywanym do druku III tomie przekładu Listów św. Ambrożego).

${ }^{38}$ Epistula 73 (ad Valentinianum), 7, CSEL 82/3, 37-38: „Paenitet lapsus, vetusta canities pudendi sanguinis traxit ruborem. Non erubesco cum toto orbe longaeva converti. Verum certe est quia nulla aetas ad perdiscendum sera est. Erubescat senectus quae emendare se non potest. Non annorum canities est laudanda sed morum. Nullus pudor est ad meliora transire. Hoc solum habebam commune cum barbaris quia deum antea nesciebam", thum. P. Nowak, (thumaczenie zawarte w przygotowywanym do druku III tomie przekładu Listów św. Ambrożego).

${ }^{39}$ Por. tamże 28, CSEL 82/3, 48. 
Podobny wydźwięk posiadają słowa Ambrożego w cytowanym już wyżej liście (14*), skierowanym do Kościoła w Vercelli, gdzie Biskup Mediolanu analizuje między innymi rozwój idei kapłaństwa w Starym i Nowym Testamencie. Interpretując laskę Aarona, która zakwitła, Mediolańczyk stwierdza:

„Wydaje się, [że przez to] objawia się, iż najstarszy lud kapłański, zepsuty w starości długotrwałej niewierności, w ostatnich czasach, przywrócony do gorliwego szukania wiary i pobożności przez naśladowanie [przykładu] Kościoła, dzięki powracającej łasce ponownie wyda kwiat, obumarły już od tylu wieków"40.

Podobnie jak wyżej, tak i tu Ambroży zaznacza, że nawet starość jest odpowiednia do tego, aby się nawrócić, aby pomimo ,starości długotrwałej niewierności” szukać prawdziwej wiary i Kościoła, co w okresie sporów ariańskich miało z pewnością jednoznaczny wydźwięk.

Jak widać z wyżej przytoczonych fragmentów listów św. Ambrożego z Mediolanu, nie przemilcza on interesującego nas problemu, lecz prezentuje głęboki szacunek wobec starości i poświęca jej niemało uwagi. Ukazuje ją jako czcigodny, charakteryzujący się przede wszystkim dojrzałością w wierze i w obyczajach okres życia człowieka. Starość dla Ambrożego nie jest mierzona liczbą lat, ani siwymi włosami, lecz dojrzałymi wyborami i postępowaniem. Wyraźnie, a jednocześnie z pewnym ostrzeżeniem dla tych, którzy chcieliby zakłócić naturalny bieg czasu, Ambroży w jednym ze swych ostatnich listów (14*) zauważa:

„Są tacy młodzi, którzy chcieliby szybko osiagnąć starość, aby nie podlegać już dłużej woli starszych; są też tacy starsi, którzy, gdyby mogli, chcieliby powrócić do młodości. Nie pochwalam pragnienia ani jednych ani drugich, ponieważ młodzi, odczuwając niechęć do spraw obecnych, są jakby niewdzięczni i szukają zmiany życia, a starsi - jego przedłużenia; tymczasem i młodzi mogą okazać się dojrzałymi przez swoje obyczaje i starzy mogą być młodymi przez swoje czyny. Albowiem to dyscyplina, bardziej niż wiek, przynosi poprawę obyczajów. Zatem o ileż bardziej powinniśmy wznosić nadzieję do Królestwa Bożego, gdzie będzie nowe życie, gdzie dokona się przemiana łaski, a nie wieku! ${ }^{11}$ ”.

${ }^{40}$ Epistula 14* (63), 58, CSEL 82/3, 265: „Declarari videtur populus senior sacerdotalis longaevae infidelitatis vetustate cariosus quod ultimis temporibus imitatione ecclesiae reformatus in studia fidei et devotionis emortuum iam tot saeculis rediviva gratia florem remittat", thum. P. Nowak (w przygotowywanym przekładzie).

${ }^{41}$ Tamże 98, CSEL 82/3, 288-289: „Sunt iuvenes qui cito volunt ad senectutem pervenire, ne subiaceant diutius seniorum arbitrio; sunt etiam senes qui velint si possint ad iuventutem redire. Quorum studium neutrum probo, quia iuvenes fastidiosi praesentium quasi ingrati mutationem vivendi requirunt, senes dilationem, cum possit et iuventus senescere moribus et senectus virere operibus. Neque enim emendationem morum magis aetas affert quam disciplina. Quanto ergo magis nos oportet spem 
Każdy więc, niezależnie od wieku, zobowiązany jest do doskonalenia się i przeżywania swojego czasu życia, jednakże nie najważniejszy jest upływ czasu i ludzkie myślenie o starości. Według Ambrożego - co można zauważyć z wyżej przytoczonych fragmentów jego listów - najważniejsza jest owa ,przemiana łaski”, owo nawrócenie, wydoskonalenie się, które jest szczególnym atrybutem starości i które dokonuje się właśnie u kresu życia każdego człowieka.

\section{AMBROSE IN HIS LETTERS ON SENILITY}

\section{(Summary)}

The correspondence of St Ambrose, of which 91 letters survive, provides a picture of his pastoral and social activities. His letters were directed to people of differing ages and classes; in some of them one can find his views on ageing, its features and dangers and how the old should be cared for. The period of old age is, according to the Bishop of Milan, the period of becoming a perfect men. Ambrose considered that with advancing age man grows towards perfection and maturity in the human sense, but more importantly in the moral and religious sense. He taught that everyone must try to improve themselves gradually throughout life by conversion and repentance, achieving maturity and perfection by the time of death.

attollere ad regnum dei, ubi vitae novitas, ubi gratiae erit non aetatis commutatio?", thum. P. Nowak (w przygotowywanym przekładzie Listów św. Ambrożego). 
